\title{
A comparative analysis on the physico-chemical composition of four different varieties of jute seeds before and after germination
}

\author{
Mominul Hoque, \\ Zahangir Alam Saud ${ }^{*}$ \\ Jahangir Alam, \\ Belal Uddin, \\ Nurul Absar \\ Department of Biochemistry \\ and Molecular Biology, \\ University of Rajshahi, \\ Rajshahi-6205, Bangladesh
}

Jute (Chorchorus capsularis), one of the most important commercial crops, is widely cultivated in Bangladesh. A comparative analysis of major nutrients of jute seeds was analyzed before and after germination. Different varieties of jute seeds contain moisture with a range of 6.6 to $7.7(\mathrm{~g} \%)$ whereas for ash it is 3.5 to $5.6(\mathrm{~g} \%)$. The total protein content was found to range between 105 and $157.5 \mathrm{mg} / \mathrm{gm}$ before germination and between 191.5 and $227.5 \mathrm{mg} / \mathrm{gm}$ after germination. The water soluble protein content was found to range between 41.2 and $53.2 \mathrm{mg} / \mathrm{gm}$ and between 65.2 and $94.2 \mathrm{mg} / \mathrm{gm}$ before and after germination, respectively. The results indicated that the protein content increased remarkably after germination. Total sugar content of jute seeds was found to range between 7 and $15 \mathrm{mg} / \mathrm{gm}$ and between 3 and $10 \mathrm{mg} / \mathrm{gm}$ while total lipid content was 182.1 to $268.7 \mathrm{mg} / \mathrm{gm}$ and 191.7 to $297.2 \mathrm{mg} / \mathrm{gm}$ before and after germination, respectively.

Key words: Chorchorus capsularis, jute, seeds, germination

\section{INTRODUCTION}

Jute (Corchorus olitorius Linn.; family: Tiliaceae), an indigenous plant to Bangladesh and India, is well reputed for its cambium fiber and for its application as folk medicine [1]. Bangladesh is an agro-based country and jute is one of the most familiar and widely cultivated commercial crops. It has an important role in the economic field of the country. This is also one of the cheapest natural fibers, and is second to cotton in world consumption [2]. Jute is not easily affected by any disease and cannot be infected by insects. This resistance is given by some proteins present in the seeds such as lectins which are toxic in nature [3-5].

Seed germination is a key developmental process in the plant life cycle and may be involved in many signal transduction pathways and their interactions, including phytohormone, sugar, and G-protein-mediated signaling [6]. Most of the plant seeds are composed of proteins and

\footnotetext{
* Corresponding author. E-mail: zasaud@yahoo.com
}

most of seed proteins are glycoproteins. In general, plant seeds contain 1-3\% carbohydrate with some exceptions [7]. Many different types of monosaccharide derivatives have been found in glycoproteins whereas some glycoproteins also contain oligosaccharide units. All plant seeds are also a rich source of lipid which acts as a concentrated fuel to produce energy. It is reported that $15-24 \%$ of lipid are found in different varieties of jute seeds in Bangladesh [8]. Corchorus seeds show a high degree of dormancy which can be broken by means of hot water treatment. It has been recorded to establish naturally from seeds and tolerate a wide range of soils and climates [9-10].

However, very scanty reports [11-12] have been published on the chemical analysis of jute seeds, but the biochemical composition during germination of jute seeds grown in Bangladesh are not yet known. The present communication is mainly concerned with the chemical analysis of four different varieties of jute seeds available everywhere for cultivation in Bangladesh. These varieties have been selected to analyze their physico-chemical parameters and nutritional aspects. 


\section{MATERIALS AND METHODS}

Four different types of jute seeds of white type jute fiber were collected from the local market of Rajshahi, Bangladesh during the period of sowing (May-June). The varieties were as follows: BADC (Tosha-O-9887), Krishi Kallan (Chakra Marka, JRO-524), Dhansamudra and Bankim (JRO-524).

Four different varieties of jute seeds were brought to the Protein and Enzyme Research Laboratory, Department of Biochemistry and Molecular Biology, University of Rajshahi, Bangladesh for experimental purposes. The seeds were washed properly and kept for 24 hours at room temperature with appropriate water, air and light for germination. The physical and chemical parameters have been studied before and after germination stages.

Moisture content of jute seeds was assessed by a conventional method while ash content was determined by the method of A.O.A.C [13]. Total and water soluble protein content were determined by the method of Micro-Kjeldal [14] and Lowry et al. [15], respectively. Total sugar content of jute seeds was determined colorimetrically by the anthrone method as described in Laboratory Manual of Biochemistry [16] while total lipid was determined by the method of Bligh and Dyer [17].

\section{Statistical analysis}

All data were expressed as the mean and standard deviation (SD) of three experiments and were subjected to one way analysis of variance (ANOVA). Mean values were compared at $\mathrm{P}<0.05$ significant level by Duncan's multiple range test using SPSS 10.0 software package.

\section{RESULTS AND DISCUSSION}

The BADC variety contained the highest amount of moisture $(7.7 \mathrm{gm} \%)$ compared with other three varieties (Table 1). The moisture content of different varieties was found to vary between $6-8 \%$. The jute seeds contained about $6 \mathrm{gm} \%$ ash, except Bankim variety which contained a significantly lower amount of ash (3.5 gm\%). The BADC and Krishi Kallan varieties contained $5.6 \mathrm{gm} \%$ and $5.9 \mathrm{gm} \%$ ash, respectively. The present data clearly indicate that in general jute seeds contained a sufficient amount of ash (Table 1).
Protein plays a crucial role in nearly all biological processes. Although animal kingdom is the main source of proteins, plant kingdom also supplies a lot of proteins. Plants accumulate and store proteins in protein storage vacuoles during seed development and maturation. Upon seed germination, these storage proteins are mobilized to provide nutrients for seedling growth [18]. However, little is known about the molecular mechanisms of protein degradation during seed germination. The amount of total protein and water soluble protein content in different varieties of jute seeds before and after germination are presented in Table 2. Bankim variety contained the highest amount of total protein and it was 157.5 and $277.5 \mathrm{mg} / \mathrm{g}$ before and after germination, respectively.

The seeds contained a significantly less amount of water soluble proteins and their content was found to vary between $40-50 \mathrm{mg} / \mathrm{gm}$ before germination. The results clearly indicate that the protein content of jute seeds determined in both processes (i. e. total protein and water soluble protein) increased after germination. The increased amount of protein in the germinated seeds might be due to synthesis of proteins by the nucleus for the enzymatic catalysis, developments and maturation of buds. Tarasevičienè et al. [19] also reported that the amounts of crude proteins in seeds significantly increased during germination, compared with the raw seeds of broccoli.

Jute seeds are a poor source of sugar and before germination stage the highest amount of sugar was present in Bankim seeds $(15 \mathrm{mg} / \mathrm{gm})$ and the lowest amount in Krishi Kallan $(7 \mathrm{mg} / \mathrm{g})$ while after germination stage, the amount of sugar became $10 \mathrm{mg} / \mathrm{gm}$ and $3 \mathrm{mg} / \mathrm{gm}$ in Bankim and Krishi Kallan, respectively (Table 3 ). The results indicate that total sugar content of jute seeds decreased after germination. During germination, there was a decrease in storage carbohydrates and this might be due to requirement of energy by a growing plant at the initial stages of seed germination. These results are in compliance with the findings for chickpea and greengram [20] and also for white beans [21].

The seeds are a good source of lipid in plant kingdom. Fats are a concentrated form of energy and are important carriers of certain vitamins. The lipid content of jute seeds increased after germination (Table 3 ) and the highest amount of lipid was found to be 268 and $299.2 \mathrm{mg} / \mathrm{g}$ dry mass for Bankim variety before and after germination. The

Table 1. Moisture and ash content of different varieties of jute seeds

\begin{tabular}{ccc}
\hline $\begin{array}{c}\text { Name of } \\
\text { the varieties }\end{array}$ & $\begin{array}{c}\text { Moisture content } \\
\text { (gm\%) }\end{array}$ & $\begin{array}{c}\text { Ash content } \\
\text { (gm \%) }\end{array}$ \\
\hline BADC & $7.7 \pm 0.01$ & $5.6 \pm 0.01$ \\
\hline Krishi Kallan & $6.1 \pm 0.03$ & $5.9 \pm 0.02$ \\
\hline Dhansamudra & $7.6 \pm 0.02$ & $6.0 \pm 0.01$ \\
\hline Bankim & $6.6 \pm 0.01$ & $3.5 \pm 0.02$ \\
\hline
\end{tabular}


A comparative analysis on the physico-chemical composition of four different varieties of jute seeds before and after germination 139

Table 2. Total protein and water soluble protein content of different varieties of jute seeds

\begin{tabular}{c|c|c|c|c|c|c}
\hline \multirow{2}{*}{$\begin{array}{c}\text { Name of } \\
\text { the varieties }\end{array}$} & \multicolumn{3}{|c|}{ Total proteins } & \multicolumn{3}{c}{ Water soluble proteins } \\
\cline { 2 - 7 } & $\begin{array}{c}\text { Before ger- } \\
\text { mination } \\
\text { (mg/g dry seed) }\end{array}$ & $\begin{array}{c}\text { After germination } \\
\text { (mg/g dry seed) }\end{array}$ & $\begin{array}{c}\text { Change } \\
\mathbf{( g \% )}\end{array}$ & $\begin{array}{c}\text { Before germination } \\
\text { (mg/g dry seed) }\end{array}$ & $\begin{array}{c}\text { After ger- } \\
\text { mination } \\
\text { (mg/g dry seed) }\end{array}$ & $\begin{array}{c}\text { Change } \\
\text { (g\%) }\end{array}$ \\
\hline BADC & $105.0^{\mathrm{a}} \pm 2.3$ & $210.0^{\mathrm{a}} \pm 1.1$ & 10.5 & $41.2^{\mathrm{a}} \pm 1.1$ & $65.2^{\mathrm{a}} \pm 0.9$ & 2.4 \\
\hline Krishi Kallan & $140.0^{\mathrm{a}} \pm 2.1$ & $192.5^{\mathrm{a}} \pm 2.3$ & 5.2 & $53.2^{\mathrm{a}} \pm 0.8$ & $83.3^{\mathrm{a}} \pm 2.2$ & 3.0 \\
\hline Dhansamudra & $131.0^{\mathrm{a}} \pm 1.1$ & $191.5^{\mathrm{a}} \pm 3.2$ & 11.0 & $50.0^{\mathrm{a}} \pm 1.2$ & $94.2^{\mathrm{a}} \pm 1.2$ & 4.4 \\
\hline Bankim & $157.5^{\mathrm{a}} \pm 3.2$ & $227.5^{\mathrm{a}} \pm 2.1$ & 7.0 & $41.6^{\mathrm{a}} \pm 2.1$ & $81.5^{\mathrm{a}} \pm 1.1$ & 3.9 \\
\hline
\end{tabular}

Values represent means of triplicate determination \pm standard deviations (SD). Means followed by the same letter across a row are not significantly different according to Duncan's test $(\mathrm{P}<0.05)$.

Table 3. Total sugar and lipid content of different varieties of jute seeds

\begin{tabular}{c|c|c|c|c|c|c}
\hline \multirow{2}{*}{$\begin{array}{c}\text { Name of } \\
\text { the varieties }\end{array}$} & \multicolumn{3}{|c|}{ Total sugar } & \multicolumn{3}{c}{ Total lipid } \\
\cline { 2 - 8 } & $\begin{array}{c}\text { Before ger- } \\
\text { mination } \\
\text { (mg/g dry seed) }\end{array}$ & $\begin{array}{c}\text { After germination } \\
\text { (mg/g dry seed) }\end{array}$ & Change (g\%) & $\begin{array}{c}\text { Before ger- } \\
\text { mination } \\
\text { (mg/g dry seed) }\end{array}$ & $\begin{array}{c}\text { After ger- } \\
\text { mination } \\
\text { (mg/g dry seed) }\end{array}$ & $\begin{array}{c}\text { Change } \\
\text { (g\%) }\end{array}$ \\
\hline BADC & $13.0^{\mathrm{a}} \pm 0.7$ & $6.9^{\mathrm{a}} \pm 0.3$ & 0.6 & $226.5^{\mathrm{a}} \pm 2.1$ & $263.9^{\mathrm{a}} \pm 1.2$ & 3.7 \\
\hline Krishi Kallan & $7.0^{\mathrm{a}} \pm 0.4$ & $3.0^{\mathrm{a}} \pm 0.1$ & 0.5 & $200.0^{\mathrm{a}} \pm 1.3$ & $229.3^{\mathrm{a}} \pm 1.3$ & 2.9 \\
\hline Dhansamudra & $12.0^{\mathrm{a}} \pm 0.3$ & $7.3^{\mathrm{a}} \pm 0.5$ & 0.4 & $182.1^{\mathrm{a}} \pm 1.2$ & $191.7^{\mathrm{a}} \pm 1.1$ & 0.9 \\
\hline Bankim & $15.0^{\mathrm{a}} \pm 0.4$ & $10.0^{\mathrm{a}} \pm 0.7$ & 0.5 & $268.7^{\mathrm{b}} \pm 1.1$ & $297.2^{\mathrm{a}} \pm 2.3$ & 2.8 \\
\hline
\end{tabular}

Values represent means of triplicate determination \pm standard deviations (SD). Means followed by the same letter across a row are not significantly different according to Duncan's test $(P<0.05)$.

range of lipid content in four different varieties of jute seeds was found to be $180-270 \mathrm{mg} / \mathrm{g}$ and $190-300 \mathrm{mg} / \mathrm{g}$ before and after germination, respectively. Total lipid content increased from 0.9 to 3.7 ( $\mathrm{g} \%$ ) of four varieties of germinated jute seeds and there is a significant $(\mathrm{P}<0.05)$ increase in Bankim variety after germination (Table 3 ).

Received 05 October 2011 Accepted 19 November 2011

\section{References}

1. Chopra RN, Nayar SL, Chopra IC. Glossary of Indian Medicinal Plants (Publication and Information Directorate, CSIR, New Delhi), 1956; 77.

2. Encyclopedia Britanica, Volume 13.

3. Linear IE, Sharon N, Goldstein IJ (eds.). The Lectins: Properties, Functions, and Applications in Biology and Medicine, Academic Press, Orlando, FL, 1986.

4. Sharon N, Lis H. Lectons. Champan and Hall, London, 1989: 127.

5. Lis $\mathrm{H}$, Sharon N. Lectins as molecules and as tools. Ann Rev Biochem 1986; 55: 35-67.

6. Koornneef M, Bentsink L, Hilhorst H. Seed dormancy and germination. Curr Opin Plant Biol 2002; 5: 33-6.

7. Lis $\mathrm{H}$, Sharon N. The biochemistry of plant lectins (phytohemagglutinins). Ann Rev Biochem 1973; 42: 541-74.
8. Hossen M, Ali MS, Begum M, Khatton A, Halim A. Study on high yield of quality jute seed production for diversified uses. J Innov Dev Strat 2008; 2(3): $71-3$.

9. Schippers R, Maundu P, Imbuni M, Obiero H. How to grow and use Jew's Mallow. Horticultural Development Services, Baarn. The Netherlands. 2002; 10.

10. Oladiran JA. Effect of stage of harvesting and seed treatment on germination, seedling emergence and growth in Corchorus olitorius 'Oniyaya'. Sci Hortic 1986; 28: 227-33.

11. Afolabi AO, Oke OL. Preliminary studies on the nutritive values of some cereal-like grains. Nutr Rep Int 1981; 24(2): 389-94.

12. Laskar S, Majumdar SG, Basak B. Chemical investigation of jute (Corchorus olitorius, Linn.) seed protein. Appl Biochem Biotechnol 1987; 14: 253-7.

13. A. O. A. C. Official Method of Analysis, 13th edition, Association of Official Analytical Chemist., Washington, D. C. $1998 ; 376-84$.

14. Wong SY. The use of persulphate in the estimation of nitrogen by the Arnold-Gunning modification of Kjeldahl's method. J Biol Chem 1923; 55: 427.

15. Lowry OH, Rosebroug N, Farr N., Randel RJ. Protein measurement with the Folin Phenol Reagent. J Biol Chem 1951; 193: 265-75.

16. Jayarman J. Laboratory Manual of Biochemistry, 1st edition, Wiley Estern Ltd., New Delhi, 1981; 53-75. 
17. Bligh EG, Dyer WJ. Total lipid extraction and purification. Can J Biochem Physiol 1959; 37: 911.

18. Junqi W, Yubing LS, Wan L, Stefan H, Samuel SM, David GR, Liwen J. Protein mobilization in germinating mung bean seeds involves vacuolar sorting receptors and multivesicular bodies. Plant Physiol 2007; 143: 1628-39.

19. Tarasevičienė Ž, Danilčenko $H$, Jarienė E, Gajewski APM. Changes in some chemical components during germination of broccoli seeds. Not Bot Hort Agrobot Clu 2009; 37(2): 173-6.

20. Jaya TV, Venkataraman LV. Changes in carbohydrate constituents of chickpea and greengram during germination. Food Chem 1981; 7(2): 95.

21. Kon S, Olson AC, Frederick DP, Eggling SD, Wagner JR. Effect of different treatments on phytate and soluble sugars in California small white beans (Phaseolus vulgaris). J Food Sci 1973; 38: 215. 